\title{
THE PREDICTION OF WATERS TROPHIC STATUS BASED ON THE CONTENTS OF NUTRIENT AND CHLOROPHYLL-A THROUGH THE TROPHIC INDEX AT THE ESTUARY OF KETINGAN RIVER, SIDOARJO
}

\author{
Diniariwisan Damai* ${ }^{\star}$ Student \\ Herawati Endang Yuli, Mahmudi Mohammad, Lecturers \\ Fisheries and Marine Science Faculty, Universitas Brawijaya, Indonesia \\ ${ }^{*}$ E-mail: mynamedamaii20@gmail.com
}

\begin{abstract}
Eutrophication is a process of abundant increasing of nutrient contents (nitrate and phosphate) in waters which can stimulate the process of algae blooming and can decrease the quality of waters. This research aims to know the trophic status based on the contents of nutrient and chlorophyll-a at the eastuary of Ketingan river, Sidoarjo on March 2018. The main parameter that was measured in this research is dissolved inorganic nitrogen and dissolve inorganic phosphate, chlorophyll-a and the dissolved oxygen that as main component to predict the fertility status by using the TRIX method. The trophic status that was got at the estuary of Ketingan river, Sidoarjo using the TRIX method shows the value of 1.21 to 2.30 , means, it is included in oligotrophic waters category.
\end{abstract}

\section{KEY WORDS}

Eutrophication, estuary, chlorophyll-a, trophic index, waters.

Ariver estuary is as a transition ecosystem between fresh and sea water. An estuary area gets a lot of load of organic materials from the land especially the domestic waste from the settlement which is washed away flowing of river until to the estuary in the sea shore area (Hutabarat and Evans, 2008). The estuary of Ketingan river is located between the Buduran and Sidoarjo Sub Regency-Sidoarjo. This area has potence of waters resource and important life supporting function and used by the people in the society as the catching fish area, fishermen route to the gulf and sea, also as the mangrove conservation in Sidoarjo Regency.

The condition of the Ketingan estuary was turbid enough at that time and was founded a lot of waste. That case can't be separated by the influence of the people's activities in the society. Antropogenic waste from the household which thrown away to the river can increase the nutrient content, like nitrate $(N)$ and phosphate $(P)$ at the estuary, in which this element is needed for the growth of the aquatic organism, phytoplankton. The height of the nutrient content in the waters can stimulate the eutrophication process that indicates the worse aquatic surroundings (Qiu et al., 2010).

The waters trophic status can be analyzed through the physics, chemistry and biology parameter by using the fertility index approach that in general is illustrated in the three levels; oligotrophic, mesotrophic and eutrophic. The load of organic material usually brings suspended particles, nutrient and dissolved organic materials that will support the rocess of eutrophication and can cause the decrease of light penetration in the depth of water. It influences the content of chlorophyll-a in waters, because the process of eutrophication usually will stimulate the phytoplankton blooming process if it is supported by the suitable sunlight for photosynthesis. This research has the purpose to know the condition of the trophic status at the Ketingan river estuary in Sidoarjo Regency, based on the content of nutrient and chlorophyll-a by using the trophic index (TRIX) method.

\section{MATERIAL AND METHODS OF RESEARCH}

This research was conducted in the Ketingan estuary and implemented in March 2018, with the number of locations as much as 3 stations (Figure 1) and 3 repetitions. 
Determination of the station according to the different character of the waters where station 1 is the estuary area closest to the settlement, station 2 is Permisan bay area, station 3 is the outside of bay area overlooking the sea (Madura strait).

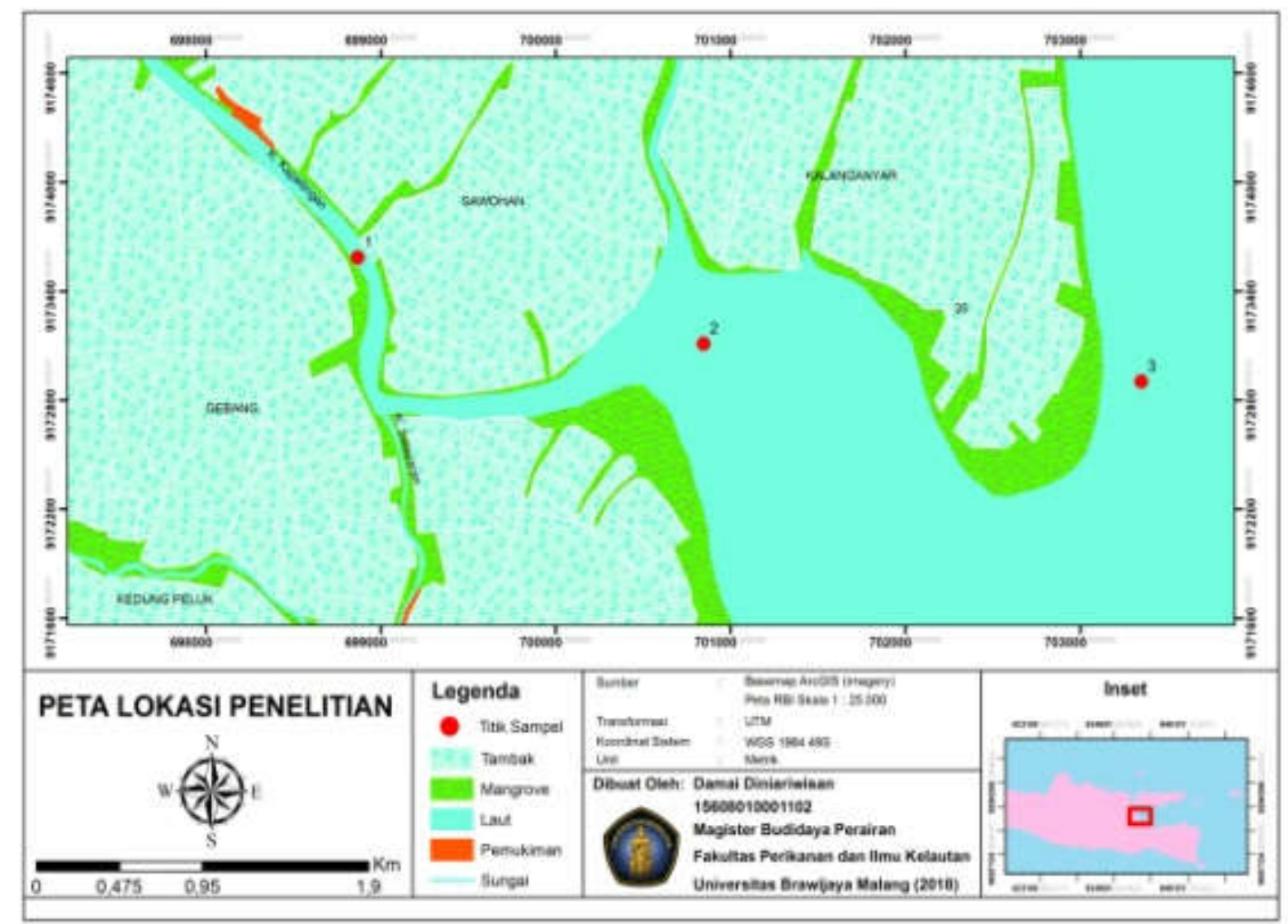

Figure 1 - Research Location Map

The parameters measured include physical, chemical and biological parameters divided into main parameters (DIN, DIP, chlorophyll-a and DO) and supporting parameters (temperature, brightness, current velocity, salinity and $\mathrm{pH}$ ).

Chlorophyll-a analysis was carried out by taking 1 liter of water samples at the site and inserted in dark bottles, and then stored in a cool box, for analyzed in a laboratory by formula (Parsons et al., 1984):

$$
\text { Chlorophyl }-\mathrm{a}\left(\frac{\mathrm{mg}}{\mathrm{l}}\right)=\left(\frac{\mathrm{Ca} \times \mathrm{Va}}{\mathrm{V} \times \mathrm{d}}\right)
$$

Where:

$\mathrm{Va}=$ Aseton volume $(10 \mathrm{ml})$;

$V=$ Filtered water sampel volume $(\mathrm{ml})$;

$\mathrm{d}=$ cuvet diameter $(1 \mathrm{~mm})$;

$\mathrm{Ca}=(11,6 \times \mathrm{E} 665)-(1,31 \times \mathrm{E} 645)-(0,14 \times \mathrm{E} 630)$;

$\mathrm{E}=$ Absorbance at different wavelengths (corrected with $750 \mathrm{~nm}$ wavelengths).

Trophic status is determined by the TRIX (Trophic Index) method, the scale is classified between 0 - 10 (Table 1) using 4 parameters ie chlorophyl-a, oxygen saturation, total $\mathrm{N}$ and $\mathrm{P}$ with equation of formula:

$$
\mathrm{TRIX}=\left(\frac{\log (\mathrm{Chl}-\mathrm{a} \times \% 02 \times \mathrm{DIN} \times \mathrm{DIP})+1,5}{1,2}\right)
$$


Where:

TRIX = Trophic index value;

Chl-a = Chlorophyll-a concentration $(\mathrm{mg} / \mathrm{l})$;

$\mathrm{DIN}=\mathrm{NH}_{4}+\mathrm{NO}_{2}+\mathrm{NO}_{3}(\mathrm{mg} / \mathrm{l})$;

$\mathrm{DIP}=\mathrm{PO}_{4}(\mathrm{mg} / \mathrm{l})$

$\% \mathrm{O} 2$ = Oxygen saturation [(DO/Doi $) \times 100 \%]$;

DOi $=$ Oxygen absolute.

Table 1 - TRIX Scale Factor Index (Tammi et al. 2015)

\begin{tabular}{ll}
\hline TRIX Value & Trophic Status \\
\hline $0<$ TRIX $<4$ & Oligotrophic \\
$4<$ TRIX $<5$ & Mesotrophic \\
$5<$ TRIX $<6$ & Eutrophic \\
$6<$ TRIX $<10$ & Hypertrophic \\
\hline
\end{tabular}

\section{RESULTS AND DISCUSSION}

Water quality can be used as an indicator of trophic status. Water quality conditions at the Ketingan Estuary are presented in Table 2.

Table 2 - Water Quality Measurement Result

\begin{tabular}{|c|c|c|c|c|c|c|c|c|c|c|}
\hline \multirow[t]{3}{*}{ Parameter } & \multirow[t]{3}{*}{ unit } & \multicolumn{9}{|l|}{ Time } \\
\hline & & $1 \mathrm{st}$ & & & 2nd & & & $3 r d$ & & \\
\hline & & St 1 & St 2 & St 3 & St 1 & St 2 & St 3 & St 1 & St 2 & St 3 \\
\hline Temperature & ${ }^{\circ} \mathrm{C}$ & 30 & 31 & 31 & 30 & 31 & 31 & 30 & 30 & 31 \\
\hline Brightness & $\mathrm{m}$ & 0,34 & 0,34 & 0,37 & 0,35 & 0,41 & 0,42 & 0,33 & 0,38 & 0,44 \\
\hline Current velocity & $\mathrm{m} / \mathrm{s}$ & 0,4 & 0,3 & 0,6 & 0,5 & 0,2 & 0,4 & 0,6 & 0,5 & 0,6 \\
\hline Salinity & $\mathrm{ppt}$ & 0 & 7 & 28 & 1 & 6 & 30 & 1 & 8 & 28 \\
\hline $\mathrm{pH}$ & - & 7 & 8 & 8 & 7 & 8 & 8 & 7 & 7 & 8 \\
\hline DO & $\mathrm{mg} / \mathrm{l}$ & 4,1 & 4,7 & 5,2 & 4,2 & 5,4 & 5,6 & 4 & 4,4 & 5,3 \\
\hline $\mathrm{NH}_{4}$ & $\mathrm{mg} / \mathrm{l}$ & 0,06 & 0,07 & 0,05 & 0,08 & 0,06 & 0,06 & 0,08 & 0,03 & 0,04 \\
\hline $\mathrm{NO}_{2}$ & $\mathrm{mg} / \mathrm{l}$ & 0,03 & 0,01 & 0,02 & 0,01 & 0,001 & 0,01 & 0,04 & 0,01 & 0,01 \\
\hline $\mathrm{NO}_{3}$ & $\mathrm{mg} / \mathrm{l}$ & 1,52 & 1,39 & 1,23 & 2,27 & 1,53 & 1,21 & 2,12 & 1,7 & 1,84 \\
\hline $\mathrm{PO}_{4}$ & $\mathrm{mg} / \mathrm{l}$ & 0,19 & 0,03 & 0,01 & 0,27 & 0,03 & 0,02 & 0,31 & 0,04 & 0,01 \\
\hline Chlorophyl-a & $\mathrm{mg} / \mathrm{l}$ & 0,44 & 0,59 & 0,84 & 0,51 & 0,78 & 1,54 & 0,39 & 0,66 & 1,08 \\
\hline
\end{tabular}

The concentration of dissolved oxygen (DO) ranges from 4 to $5.6 \mathrm{mg} / \mathrm{l}$. Based on Table 2 shows the occurrence of increased DO that leads to the sea. This is allegedly caused by the influence of freshwater inputs from rivers into the bay carrying pollution materials both in organic and organic form. So there is a decomposition of inorganic materials process that can reduce DO levels. According to Giovanardi and Vollenweider (2004), decomposition of organic matter and the oxidation of inorganic materials can reduce DO to 0 or anaerobes. In addition, DO also depends on the mixing and water mass movement process, photosynthesis and respiration activity.

Nitrate $\left(\mathrm{NO}_{3}\right)$ and orthophosphate $\left(\mathrm{PO}_{4}\right)$ concentration during the study activity showed a fairly high number. According to Mustofa (2015), water with ranges $1-5 \mathrm{mg} / \mathrm{l}$ of nitrate is mesotrophic. In addition,

Effendi (2003) added that nitrate concentrations more than $0.2 \mathrm{mg} / \mathrm{l}$ can lead to eutrophication which further able to trigger the rapid growth of algae (blooming), whereas for orthophosphate concentration with values $0.011-0.03 \mathrm{mg} / \mathrm{l}$ including mesotrophic, and $0.031-0.1 \mathrm{mg} / \mathrm{l}$ including eutrophic. This high $\mathrm{N}$ and $\mathrm{P}$ concentration may caused by the influence of anthropogenic activities such as residual water debris of pond farm activities that dominate the area around the estuary. In addition, the settlement at the edge of the estuary (station 1) can be a source of nutrient waste that potentially increases the trophic status of the waters. According to Brigden and Stringer (2000), waste with nitrogen content is largely derived from the secretions of mammals, nitrogen fertilizers, agricultural fertilizers and erosion. 
The measured chlorophyll-a concentration during the research ranged from 0.39 to $1.54 \mathrm{mg} / \mathrm{l}$ (Table 2). This value indicates a less variable range. Generally the highest concentration of chlorophyll-a is found in areas with the rich nutrients, but it is different from the conditions at the Ketingan estuary. The distribution of chlorophyl-a concentration is relatively higher in the lower nutrient areas, but has a higher brightness value. This indicates that beside of to the availability of adequate nutrients, sunlight is also needed to support the photosynthesis process by phytoplankton, in order to produce chlorophyll-a.

Table 3 - The Waters Trophic Status at Ketingan estuary

\begin{tabular}{llll}
\hline Time & Station & TRIX Value & Trophic Status \\
\hline 1 & 1 & 1,97 & Oligotrophic \\
& 2 & 1,43 & Oligotrophic \\
& 3 & 1,21 & Oligotrophic \\
2 & 1 & 2,30 & Oligotrophic \\
& 2 & 1,61 & Oligotrophic \\
& 3 & 1,70 & Oligotrophic \\
& 1 & & Oligotrophic \\
& 2 & 2,21 & Oligotrophic \\
& 3 & 1,63 & Oligotrophic \\
\hline
\end{tabular}

The TRIX index is one of the most commonly used indexes in assessing the trophic level of a waters in monitoring the condition of aquatic eutrophication through the total parameters of nitrogen, total phosphate, saturated oxygen and chlorophyll-a. The calculation results of the four parameters, will be described based on the criteria of fertility rates. The results of the TRIX index in the Ketingan estuary range from 1.21 to 2.30.

The trophic status indicated by the DIN and DIP content of nutrients gives different trophic status to the TRIX index value obtained. The presence of high $\mathrm{N}$ and $\mathrm{P}$ nutrients is estimated due to the high input of organic material from the mainland especially from anthropogenic activity waste especially fishery activities (ponds) and households around the estuary of the Ketingan River. Meanwhile, trophic status indicated by the content of chlorophyll-a gives trophic status according to TRIX index, that is oligotrophic water category. This shows that high-low chlorophyll content is not only influenced by the presence of high nutrients, but also the effect of brightness due to the phytoplankton photosynthesis process. As a constituent of phytoplankton biomass (chlorophyll-a), where high brightness (low turbidity) will affect the intensity of sunlight for the continuity of the photosynthesis process. So because of the low brightness in the waters of the Ketingan estuary makes the concentration of chlorophyll-a is low too. This is in accordance with the opinion of Effendi (2003), that the relationship of primary productivity of phytoplankton in the waters is also much influenced by the intensity of sunlight in addition to the presence of nutrients itself.

\section{CONCLUSION}

Trophic status of Ketingan estuary based on TRIX is oligotrophic, with the range value from 1.21 to 2.30. The presence of the nutrient values (Nitrate and Phosphate), indicates the trophic status from mesotrophic to eutrophic. However, the obtained of chlorophyll-a concentration tends to be low and is categorized as oligotrophic, due to the low brightness value at the study site so that the photosynthesis process is very limited.

\section{REFERENCES}

1. Brigden, $\mathrm{K}$ and Stringer R. 2000. Ammonia and Urea Production: Incidents of Ammonia Release from the Profertil Urea and Ammonia Facility, Bahia Blanca, Argentina. Greenpeace Research Laboratories, Dept of Biological Science. University of Exeter. UK. $334 \mathrm{p}$ 
2. Effendi, H. 2003. Telaah Kualitas Air. Kanisius. Yogyakarta.

3. Giovanardi, F., \& Vollenweider, R. A. (2004). Trophic Conditions of Marine Coastal Waters: Experience in Applying the Trophic Index TRIX to Two Areas of the Adriatic and Tyrrhenian Seas. Journal of Limnology. 63(2): 199-218.

4. Hutabarat, H. and M. Evans. 2008. Pengantar Oceanografi. Universitas Indonesia. Jakarta.

5. Mustofa, A. 2015. Kandungan Nitrat and Pospat Sebagai Faktor Tingkat Kesuburan Perairan Pantai. Jurnal Disprotek. 6(1): 13-19.

6. Parsons, T. R., M. Takashi, and B. Hargrave. 1984. Biological Oceanography Process. Third Edition. Pagaman Press, New York. 263p.

7. Qiu, D., Huang L., Zhang J. and Lin S., 2010. Phytoplankton Dynamics In and Near the Highly Eutrophic Pearl River Estuary, South China Sea. Continental Shelf Research. 30: 177-186.

8. Tammi, T., N. T. M. Pratiwi, S. Hariyadi and I N. Radiarta. 2015. Aplikasi Analisis Klaster and Indeks TRIX Untuk Mengkaji Variabilitas Status Trofik di teluk Pegametan, Singaraja, Bali. Jurnal Riset Akuakultur. 10 (2): 271-281. 